\title{
Using preferential trade access to promote global development goals: the case of beef and market access to Norway from Namibia and Botswana
}

\author{
Using market access to achieve developmental aims has long been held as a key \\ tenet of global development policy. Using a case study approach based on \\ interviews along and across the beef value chain between Namibia, Botswana, \\ and Norway, this article addresses the question of whether market access to high \\ value markets for livestock products has developmental benefits. The costs and \\ benefits of using market access for beef products as a developmental policy tool \\ are identified and the key role played by international meat traders in both \\ upgrading and rent capture discussed.
}

Keywords: Market access, preferential trade, beef, Norway, Namibia, Botswana

\section{Introduction}

Market access for livestock products is particularly challenging for developing countries. While many developing countries receive duty-free, quota-free access to developed markets under a range of preferential tariff arrangements, other non-tariff issues come into play for livestock, meat and meat products because they are subject to a wide array of strict sanitary and phytosanitary (SPS) protocols based on the provision of both food safety attributes and the national or regional absence of different animal diseases. Whilst most developed country markets are mature, some are quite profitable; either due to growing demand, domestic agricultural protection or through high value niche market segments. The loss of these opportunities can be significant (Perry et al. 2002:50). A further issue is the way that the benefits of market access are shared among producers, processors, and traders. Absence of market access may preclude smallholder farmers in particular from moving up the value chain where commercialization is a government objective (Perry and Rich, 2007). To what extent gaining access to these high value markets is a positive force for promoting inclusion and upgrading in emerging livestock, meat, and meat product suppliers is unclear (Perry et al. 2005:6, Perry and Sones, 2007). These questions provide the foundation for the research. Namibia and Botswana are among a small handful of developing countries that have obtained market access into a majority of major global beef markets (Scoones et al. 2008). Of particular relevance has been access to the European common market, facilitated by significant investments in biosecurity and animal health to meet strict EU 
SPS standards (Rich and Perry 2011; Naziri et al. 2015). Both countries also have access to the Norwegian market through a duty-free quota granted under preferential trading agreements between Norway and the Southern Africa Customs Union (SACU). Commonalities in the SPS regimes of the EU and Norway have facilitated this access. While economic theory highlights that quotas have the same overall welfare effects in importing countries as preferential tariffs, a key difference is that the rents associated with quotas accrue to quota holders. Using quotas as a mechanism to foster market access between Botswana/Namibia and Norway has not surprisingly politicized the beef trade, both domestically in the two African countries and in Norway (see, for example, Kaira 2018; Menges 2014; and Mguni 2019). Indeed, these developments have altered the political economy of quota administration (see Bates 1981 for a general overview), affecting the balance of power among different intermediaries in the beef value chain. In recent years, a number of conflicts associated with the administration of the quota have surfaced, raising concerns as to whether the quota fulfils its functions of regulating beef imports for Norway and pursuing the development objectives of Norway ("trade as aid"). The developmental benefits of the quota in Botswana and Namibia are also questioned.

The developmental impact of market access for meat products from Namibia and Botswana is additionally complicated by the geographical challenges that these countries face and their recent political history. Both countries are extremely arid with low and unpredictable rainfall. Namibia and Botswana have differing post-colonial narratives in which human segregation and land use influenced the domestic management of market access for livestock to international markets (Hillborn 2013; Miescher 2012).

This paper, based on a series of comprehensive interviews with actors in the value chain, provides an overview of trends and developments associated with beef production and trade from Botswana/Namibia to Norway. We highlight the role that changing industry dynamics have had on the beef trade. We then focus on some of the challenges that future trends portend for the sector, including an assessment of different future scenarios.

Objectives 
The study set itself three key questions: (1) do the attributes necessary for market access for meat and meat products shape their value chains in a specific and identifiable way; (2) do traders and other intermediaries in value chain influence the benefits to producers; and, (3) what lessons can be learned from the experience of the countries and actors involved that might guide future policy? Specifically, the paper reveals how market access quotas affect farmer, firm, and policy decisions in Norway, Namibia and Botswana. The market rationales and dynamics in each country and the extent to which the quota meets notional developmental objectives are a central reason for undertaking the research. We also consider how countries with a heavy dependence on niche markets and defined special market access (as is the case in the relationship between Botswana, Namibia and Norway) manage the risk of limited market diversification.

Conceptual framework, data and methods

This paper consists of a case study with a series of embedded units of analysis at different levels including country (Namibia, Botswana, UK, and Norway) and actor (traders, agents, policymakers, processors, researchers and farmer leaders).

We define the impact of beneficial market access for beef from Namibia and Botswana to international markets as the sum of employment, income, and quality outcomes, and hypothesize that these are influenced by a range of factors including social and physical infrastructure; access by farmers to export markets; and the various intermediaries that facilitate market access in different ways, as shown in Figure 1.

\section{[Figure 1]}

Source: authors

We adopt a case study approach based on identification of key informants, multiple sources, replication, and prior informed consent to ensure a minimum validity and reliability (Yin 2003). This study uses as its unit of analysis intermediaries in the value chain. Specific themes of enquiry, realms of response associated with the research questions, and numbers of embedded case studies (in-depth interviews) for each actor category are summarised in Table 1. 
[Table 1: conceptual framework]

Source: authors

Interviews were conducted against a set of guide questions and in each case prior informed consent was received from the interviewees against an agreement for anonymity using the University of Greenwich Ethics Policy and Code of Practice for Research (UoG 2019).

\section{An overview of the beef sectors of Botswana, Namibia, and Norway}

Cattle production and beef exports dominate the Botswana agricultural sector which consists of approximately 77,000 individual farmers, 74,200 of which are communal, small-scale, and extensive. Since independence in 1966 Botswana's cattle herd has remained between 2-3 million head, a figure that reflects the carrying capacity of the existing grazing system. Seleka (2015) shows that the share of communal farms in the cattle population has varied between 85\% and 97\% between 1995 and 2012, and suggests that this points to an underlying trend of declining commercial farming but new investors in communal cattle rearing. This trend towards increased communal farming is a challenge for productivity and for market access.

Meat exports from Botswana are controlled by the Botswana Meat Commission (BMC), a state-run parastatal. BMC maintains both monopsony power over the purchase of animals for export and monopoly power on beef exported (Mupotola et al. 1997). A historical challenge that BMC faces has been low throughput in its abattoirs, compounded by the traditionally low prices (often below export parity) paid to producers, reducing their incentives to supply BMC given more attractive prices found in domestic markets (Dizyee et al. 2017). BMC are required to return $70 \%$ of their income to producers under their Act. Traditionally, this was done with a bonus payment in December, but recent problems have meant no bonuses. The time it takes for farmers to be paid has also increased as BMC has suffered cash-flow challenges. Some years ago, farmers were paid within 48 hours of sale (having 'trekked' their animals to a selling point). Now it can take up to 14 days to be paid.

Market access for beef exports to major developed markets (USA, EU) necessitates freedom from foot-and-mouth disease (FMD). While FMD is typically not fatal for 
infected animals, it spreads rapidly and causes widespread morbidity. Most high-value markets are free of FMD, and mandate that trading partners are also free of the disease as a precondition for trade (James and Rushton 2002). Economic impacts of noncompliance can be extensive (Knight-Jones \& Rushton, 2013). In the case of Southern Africa, exporting countries are further required to maintain disease freedom without vaccination (Rich \& Winter-Nelson 2007). To ensure market access, Botswana maintains different production zones that are certified as FMD-free without vaccination by the World Animal Health Organization (OIE) that are physically separated by a double-ringed fence (see figure 2). These fences are combined with strict livestock identification and traceability protocols that are reported to cost US\$35 million to establish, and $€ 5$ million per year to maintain (Agritrade 2011). Lapses in this system during 2011 forced Botswana to shut down exports for six months and to change from a stomach bolus based system to ear tags (Moreki et al, 2012).

Cattle production and beef exports also play important roles in the agricultural economy of Namibia. Namibia had a cattle herd of approximately 2.38 million head in 2014. An important dynamic in the cattle sector in Namibia is the regional bifurcation of cattle production systems between the northern and southern parts of the country. Namibia maintains strict biosecurity controls in the form of a veterinary cordon fence (VCF) that splits the northern part of the country (with predominately smallholder communal production) from the southern part of the country where large-scale, export-oriented commercial production takes place, as shown in figure 3 (Miescher, 2012). The part of Namibia south of the VCF has been recognized as FMD-free without vaccination by the OIE, which allows market access to European market. Areas north of the VCF do not have access, as they include surveillance zones, areas in which vaccination is required, and endemic pockets of FMD (Vosloo et al, 2002). This divergence in market access is important to the Namibian government, shaping the price setting process for cattle and influencing the investments and regulatory changes proposed to find ways that improve the ability of smallholder farmers and the emerging Namibian middle classes with larger herds, to access higher-value markets. Approximately one-half of Namibia's livestock are on either side of the fence.

[Figure 2: vet disease control zones Botswana]

Source: European Commission (2013a) 
[Figure 3: vet disease control zones Namibia]

Source: European Commission (2013b)

Commercial offtakes (i.e., sales of cattle for slaughter) typically range between 10-15\% of national production, though there are wide differences between north and south, and communal and commercial production. Nationwide, about $75-80 \%$ of production comes from commercial producers, while offtakes in the northern communal areas (NCA) are about $5 \%$ of NCA stocks (Naziri et al. 2015). As illustrated in figure 4, the main destinations for live cattle have historically been either for export to South Africa (typically weaners from semi-commercial farms south of the VCF) and for slaughter by Namibia's main export-oriented abattoir, Meatco. Exports of meat from northern abattoirs are limited and primarily serve regional markets. The export of both live animals and meat from northern communal areas to South Africa is restricted by strict quarantine rules and since the FMD outbreak in 2015, exports of both animals and meat from areas north of the VCF were banned and expensive remedial measures put in place (The Namibian, 2015 and New Era, 2016).

[Figure 4: Marketed cattle in Namibia by sales 2010-16]

Source: Meatco

Prices for cattle are set by Meatco on a weekly basis based on a grading scheme (Meatco, 2018), with animals classified from A (highest grade) to C (lowest). C grade animals sell at a 20-30\% discount relative to A grade. While animals north of the VCF cannot be sold for export to high-value markets, Meatco maintains the same pricing scheme for animals sourced north and south of the VCF. This provides an implicit subsidy for producers in the NCA, even though most animals in communal areas would be $\mathrm{C}$ grade. Meatco has historically operated at a loss in its NCA abattoirs and mobile slaughter facilities, both on the basis of its pricing scheme and low throughput (Naziri et al. 2015). The obligation for Meatco to buy may result in a transfer of export value from animals south of the red line to animals in the north. This is a long held argument for maintaining Meatco's status in Namibia, but has been hard to prove.

Figure 5 illustrates the evolution of carcass prices (Namibia dollars per kg) during 201018. Prices for producers have been rising since 2010, in recent years aided by the currency weakness, with price spikes in recent years due to drought.

[Figure 5: Carcass prices for Namibian beef 2010-18] 
Source: MeatCo

The domestic beef sector in Norway has been in a slow decline. Current domestic production is around 82,000 tons, falling from about 95,000 tons in 1999, while consumption was, until recently, steadily rising to around 95,000 -100,000 tons (Rich et al. 2012). Consumption per capita has been declining slowly since 2000. Imports fill in the gap between supply and demand, with the majority of imports from the EU under supplemental quotas administered by the Norwegian Agricultural Agency (SLF). Another 3,700 tons of beef comes from SACU under different quotas described in the next section. According to unpublished data from Nortura, an agricultural cooperative and the largest processor of meat in Norway, the market for premium cuts in Norway is around 14,400 tons. Imports from SACU comprise $22 \%$ of this market, and $13 \%$ of the highest end steak/filet 'prime cuts' market.

A development over the past years has been involvement of Nortura more directly within the beef trade in Norway. Nortura's interest in trade with SACU countries has been motivated by its desire to facilitate imports in a manner not disruptive to the domestic market and as a form of corporate social responsibility to improve beef production in Botswana and Namibia. Nortura began importing small amounts of beef directly in 2009, and bought its way into the market through the purchase of an equity share in one of Namibian's few certified export-oriented abattoirs, Witvlei. The Witvlei abattoir was originally set up as an empowerment business by the Government of Namibia with a view to eventually breaking up the export monopoly of MeatCo. Since 2014, when trade with Witvlei stopped, Nortura has traded directly with Global Proteins Solutions Group (GPS), a UK-based meat broker that plays a critical role in the beef trade between SACU and Norway. GPS plays an important intermediary role between MeatCo, BMC, and retailers, providing technical support in production, logistics, and marketing for the purposes of adding value to Namibian and Botswanan beef. GPS acts as a service provider on a fee-basis and not as a traditional wholesaler or trader as such. In 2013, Nortura, through its relationship with GPS, imported about $47 \%$ of beef from SACU. 


\section{Trade dynamics and trends of beef exports from Botswana and Namibia to}

Norway

Meat exports to Norway are regulated through two sets of market access quotas. First, the free trade agreement between SACU and Norway allows for a 500-ton duty-free quota from exports from SACU countries (Botswana, Namibia, Lesotho, South Africa, Swaziland) to Norway. Second, Botswana and Namibia co-administer a World Trade Organisation (WTO) General System of Preferences (GSP) duty-free quota of 2,700 tons that is a vestige from the previous preferential trade regime Norway maintained with developing countries, with each country receiving one-half of the quota based on negotiations between Meatco and BMC (Rich et al. 2012; Aurdal \& Omholt 2013).

In figure 6, we illustrate trends in beef imports from the three SACU countries to Norway from 2011-18. Namibia has largely filled its quota of 1,600 tons in each of the five years, and was able to have Botswana's quota reallocated to Namibia in 2011 and 2012 when Botswana's trade was disrupted by FMD. An important development in beef exports from SACU has been the shift away from frozen products towards fresh offerings, and towards higher-value cuts. In figure 6, the price of fresh beef cuts is given on the secondary axis (line graphs), highlighting the steady rise in the price of fresh beef achieved by Botswana and Namibia. In figure 7, we likewise observe a strong rise in the share of fresh beef exported to Norway, where the share of fresh beef from Botswana and Namibia reached $88 \%$ in 2016. This has since levelled off, while in Swaziland, the sharp reduction in 2018 was due to the FMD-related export ban imposed by the EU.

[Figure 6: Exports of beef from SACU countries to Norway 2011-18]

Source: Statistisk sentralbyrå (Statistics Norway)

[Figure 7: Share of fresh beef imports from SACU 2011-18]

Source: Statistisk sentralbyrå (Statistics Norway)

An important distinction between these quotas concerns their administration. The 500 ton SACU quota, which is predominately shared between Namibia and Botswana, is allocated by means of an auction system, whereby once per year, Norwegian traders bid for a share of the quota (Aurdal and Omholt 2013). The gap between high and low bids tends to be relatively small, with bids ranging from a low of $0.01 \mathrm{NOK} / \mathrm{kg}$ in 2008 to a high of around $16 \mathrm{NOK} / \mathrm{kg}$ in 2010, with these relatively low quota bids (relative to the 
value of these quota rents) reflecting in part a lack of competition amongst a limited number of auction participants (ibid.). The GSP quota, by contrast, is allocated through a licensing mechanism administered in each country. In Botswana, only the BMC has quota rights, whereas in Namibia, the government allocates the quota to export-oriented abattoirs. The licensing of the GSP quota replaced the previous first-come, first-serve (FCFS) means of quota allocation in 2011, which had been problematic in that the quota would literally fill within minutes of its opening on the 1st of January each year (Rich et al. 2012).

The GSP quota has come under scrutiny as to its WTO legality (Rich et al. 2012). To be compliant, the preferential access that both countries receive would need to be subsumed under a free-trade agreement such as SACU. This is currently under discussion. It is not yet clear whether the expanded SACU quota (that would incorporate the GSP quota) will be administered as an auction or under license. Discussions with sources in the Namibian industry and government, as well as with GPS revealed that all strongly favour retaining the license mechanism. One source remarked that reverting to an auction would damage the branding and promotion investments that have been made to add value to Namibian beef, as there would not be the scale necessary to make such efforts cost-effective. GPS also note the increase in value-added products found in Norwegian supermarkets which has coincided with the movement away from traditional traders and towards a service provision arrangement. On the other hand, discussions with a beef trader suggest that the lack of competition implicit in the licensing program has reduced incentives for market and product diversification outside of the Norwegian market.

\section{How quotas influence farmer, firm and policy decisions}

What role has GSP quotas played in generating rent-seeking behaviour, and how these rents are distributed? An important aspect of the narrative revolves around how business dynamics in the meat sector have been influenced by trade with Norway, specifically in terms of (a) the allocation of quota rights internally with Namibia and (b) how the marketing of meat has evolved in response.

Arrangements on the licensing of the main GSP quota in Namibia have prompted significant rent-seeking behaviour amongst local abattoirs and Norwegian interests. In 
2011, when the quota was first allocated internally, it was distributed evenly between MeatCo, a government parastatal / producer-run cooperative, and Witvlei, a private abattoir. Witvlei was established in 1998 and run under a lease agreement with the Agribank, by one of Namibian's richest entrepreneurs with close ties to the Namibian government (New Era 2016a). The abattoir was constructed in a remote part of eastern Namibia. MeatCo historically produces about 80 percent of Namibia's export-oriented meat and had strongly argued for an allocation of the quota more in line with the current and historical trends of production.

Witvlei was $30 \%$ owned by Nortura, a large producer-owned cooperative in Norway which also plays a parallel role as the market regulator there (Aurdal \& Omhalt 2013). Previously, Witvlei had been part of a partnership between two other Norwegian trading houses, but this broke down over a price dispute (Rich et al. 2012). Nortura's stated aim was development-oriented in bringing Namibian prices up to near-Norwegian levels, although previous discussions of this have suggested that this was a means to capture margins previously held by importers (Rich et al. 2012).

Namibia's Ministry of Trade and Industry (MTI) stepped in to litigate the dispute between MeatCo and Witvlei. In 2014, the quota was reallocated such that MeatCo obtained 1,200 tons, Witvlei 300 tons, and Brukarros Meat Processors (BMP) 100 tons; the BMP quota was eventually re-allocated 50:50 when it emerged it could not meet export standards (Schlechter 2014). Witvlei ceased operations later in 2014, with Nortura resigning from the board and engaged in a dispute with meat owed to it by Witvlei (Vermes 2015). As of December 2015, Witvlei was in receivership, with its abattoir owned by Agribank, a government-owned bank (New Era 2016b) . In April 2016, Witvlei won its court case against Agribank and regained access to its abattoir.

Trading dynamics and the rents generated by trade between Namibia and Europe have been transformed by the entry of GPS, a UK-based service provider, as the main broker for exports. GPS have worked with Namibia since 2008 and Botswana since 2012. An important difference in their approach compared to past trading efforts has been on altering the product mix from predominantly frozen cuts to fresh cuts and on marketing. This has led to strong price gains, with returns increasing $132 \%$ in Namibia and $65 \%$ in Botswana since GPS began its involvement. Brand-building has been taking place in Namibia with respect to their premium "Nature's Reserve" brand. Unlike Namibia, 
Botswana has not developed a farm level standard, but intends to in the near future. By having a farm assurance scheme, Botswana will be able to brand their products in high value markets in the same way the Namibia sells its product in, for example, Denmark under the "Natures Reserve" label (Natures Reserve 2019).

However, much of the branding efforts with Nature's Reserve have focused on the European (non-Norwegian) market, despite obtaining significantly higher price premiums in Norway (see Box 1). By differentiating between different meat grades and cuts in the final markets (notably the relative insensitivity of the Norwegian consumer to beef quality factors prevalent in more competitive markets such as the UK), this firm seems to be capturing lead firm rents beyond the value of its upgrading efforts (as predicted by Trienekens 2011).

[Box 1: How Norway's indifference to beef quality allows Traders to profit] Source: various interviews

GPS sit in a network of business arrangements among the meat industries of Southern Africa, the United Kingdom and Norway. This web of ownership presents a challenge for policy makers who seek foreign investment, but who also want fair and inclusive domestic and international meat trading arrangements that engage all scales of production including the very small scale. The estimation of quota rents associated with the GSP and SACU quotas sheds some light onto these issues, although data limitations preclude a more rigorous discussion. In table 2, we update the analysis from Aurdal \& Omholt (2013) by computing estimated quota rents for Namibia (data was not available for Botswana) during 2010-18, based on prevailing farm prices (in carcass equivalent) in Namibia, export unit values for fresh beef, and estimates for wholesale prices of meat cuts in Norway. Quota rents are calculated by Aurdal and Omholt as the surplus exporters and importers receive net of the price paid for the product. For exporters, these rents are the difference between the price received and the farm price. For importers, these rents are the difference between the wholesale price and the sum of the exporter price, transport costs, and (where relevant) auction costs associated with the 
SACU quota. 1 The percentage change in these surpluses can be compared to prices farmers received from trade with Norway to glean the degree to which certain value chain actors gain more or less from this trade. Aurdal \& Omholt (2013) estimated wholesale meat prices at $183 \mathrm{NOK} / \mathrm{kg}$ for their entire data sample (2008-12), which is plausible given that domestic meat prices were largely unchanged from 2009-12 based on the CPI for beef and veal reported by SSB (Norwegian Statistical Service). However, from 2013, the prices for beef and veal rose by about $5 \%$ per year and we have updated wholesale prices accordingly.

[Table 2: Distribution of quota rents in Namibia 2010-18]

Source and notes: Sources and notes: Aurdal and Omholt (2013) for exporter, transporter, importer, and Norwegian government figures from 2010-2012 and method. Farmer prices for 2010-2018 from MeatCo (see figure 4) and converted to NOK from annual exchange rate figures of SSB; slight discrepancies can be found between our 2010-2012 figures and those of Aurdal and Omholt (2013). Exporter figures from 20132018 from SSB. Norwegian auction revenue figures from Landbruksdirektoratet, retrieved from http://auksjon.landbruksdirektoratet.no/history. Importer figures adjust the 183 NOK/kg figure from Aurdal and Omholt (2013) for 2013-2018 based on CPI figures from SSB for beef and veal. Original importer figure is used for 2010-2012. GSP refers to preferential quota for Botswana and Namibia; SACU refers to the auction used for the Norway-SACU FTA.

The results in table 2 are quite illuminating. From 2010, we observe a nominal doubling in the exporter surplus in Norwegian Kroner (NOK) terms during 2010-18. This reflects in large part the movement towards higher-value fresh cuts as facilitated by GPS. At the

\footnotetext{
${ }^{1}$ It is worth noting Aurdal \& Omholt (2013) directly compare carcass prices with those of cuts in their analysis, which is problematic given the greater transformation associated with cuts. Note that conversion rates from carcass depend on a variety of factors; see for example http://www.ansc.purdue.edu/SP/TBC/Documents/PB1822.pdf.
} 
same time, up until 2016 producer prices in nominal Namibian dollar terms had increased by about $51 \%$ (recall figure 4), while in NOK terms, farm prices have been largely flat in trend owing to the steady depreciation of the Namibian dollar. This trend showed a sharp rise upwards in 2017-2018 in part due to drought-induced pricing pressures. This implies the generation of significant, supra-normal rents by the new trading arrangements, and ones whose developmental benefits (i.e., at the farm level) are instead captured in part by these new trading arrangements. Taking the anecdotal information from box 1 into account suggests these rents net of costs are substantial, though there is some indication that more premium and higher quality meats are being sold in Norway in recent times.

By contrast, table 1 suggests that surpluses at the importer level have been steady to declining since 2011. Auction rates - revenue for the Norwegian government - on a per-kg basis for the 500 ton SACU auction have been steadily rising to a high of 15.81 $\mathrm{NOK} / \mathrm{kg}$ in 2016, then falling again in 2017-2018. As these are also increasing as a share of the export price, they imply both an increase due to the import of higher-value product and higher competition for a smaller pool of available meat by traders.

An important implication of the analysis of quota rents is the extent to which such profits have been used for the benefit Namibia and Botswana actors. It is certainly true that there have been significant investments in brand building and differentiation, and these have indeed added value in the beef sector. On the other hand, it is equally important to ask whether the monopsony buyer (MeatCo/BMC), monopoly marketer (GPS) hampers competition and innovation, and reduces the potential benefits to farmers. Another consideration is whether the Norwegian meat sector itself wants more competition with its own production. Given Nortura's role in this trade arrangement, this could stymie the potential ceiling for Namibian and Botswanan value-adding efforts. An alternative view to this upgrading through product differentiation, offered by international meat traders interviewed, was that the value addition was rather limited and that more could be achieved through promoting competition among traders for the Botswanan and Namibian access to the high value Norwegian market. However, we would argue that in the absence of scale efficiencies, differentiation and value addition are the only game in town, although the managed value chain highlighted here may place a ceiling on those potential gains. 
While the analysis in the preceding section has focused on the effects at the level of the producer and downstream in the value chain, it is worth considering the implications of such quota arrangements on the consumer, particularly in Namibia and Botswana, as well as in regional markets in Africa. In principle, the existence of high-value markets in Norway for high-value cuts ostensibly provides greater pricing flexibility of lowervalue cuts to domestic consumers, and potentially benefitting consumers, particularly lower-income groups. Indeed, the lack of product differentiation stymies the competitiveness of domestic beef production in other parts of Africa (e.g., in West Africa), while countries in South America are able to competitively segment markets and diversify sales. On the other hand, these benefits are mitigated somewhat by the over-reliance of Namibia and Botswana on the Norwegian market, raising the domestic price of animals over which would exist in the absence of the quota and making such price differentiation vis-à-vis other competitors more difficult.

\section{Quota management - how far is the benefit shared?}

Limited market access is commonly managed through the distribution of quotas. Small quotas represent a particular trade problem: how do you share the quota equitably and transparently without dispersing the volume so much that trade is no longer feasible. The most efficient system would be to offer a temporary monopoly, but this would focus rents and lead to governments being accused of favouritism. There is also a risk that firms can buy up quota and then fail to use it to take the commercial advantage over a rival.

Quota auctions are often the solution. This has been the method used at the Norwegian end of the Southern African beef trade and continues to be used for the SACU quota. Among service providers, the Norwegian auction is strongly disliked because it is believed to narrow market access and impede branding and value-adding efforts. However, from the point of view of good order, it would seem preferable to the highly suspect licensing system used previous to 2011.

On the supply side, Botswana gives its quota to BMC. Namibia has used the quota differently with the aim of giving advantage to new entrants. In 2014 when the Government of Namibia split the quota between three different abattoirs (Meatco, Witvlei and Brukarros abattoirs) it did not work perfectly. The aim had been to use 
quota to empower new, largely Government guaranteed, meat-processing investments that satisfied a more overt set of policies to re-balance the agricultural economy in Namibia in favour of the previously disadvantaged. This had several snags: firstly, Meatco complained that it lost profitable quota, but was still obliged to maintain its loss making abattoirs to the North of the VCF; secondly, Witvlei failed to meet its financial obligations and shut-down after quota was allocated; and, finally, Brukarros, won quota but could not deliver, so returned its quota to Meatco. In Namibia quotas seem to be the only alternative to the damaging dash to grab licenses that used to occur among exporters, but is far from a precise policy instrument. In Norway, quotas have facilitated an orderly trade. However, because the benefit has largely fallen in commercial farming areas, the development impact is less clear and harder to quantify.

The dynamics of quota rents in the Namibian and Botswanan cases are shaped by interactions of value chain governance and nature of agricultural protection in Norway. Most food exports are characterized by what Gereffi (1999) terms "buyer-led" chains that are coordinated by retailers, with standards and codes of conduct transmitted upstream to suppliers and intermediaries. This phenomenon has been strengthened by the consolidation of retail chains that has occurred across the developed world (Lee et al. 2012), and in Norway itself (Amilien et al. 2007). At the same time, despite the presence of niches and strong associations with local food (see Nygård \& Storstad 1998; Amilien et al. 2007), our observation is that the consolidation of retail in Norway has had less influence on shaping or transmitting consumer sovereignty outside of this space given the nature of agricultural protection and dominance of cooperatives and large firms that benefit from the protected market (e.g., Tine, Gilde). This provides a means for more of the rents associated with quota to be captured by intermediaries and not distributed in the form of branding or other value-adding efforts to benefit consumers. Indeed, as noted in the box above, that service providers like GPS can (and do) market C-quality meat at A-quality prices in the Norwegian market, and that (until recently) the majority of Namibian and Botswanan meat was either sold for food service or as lowend, private label, limits producers and consumers returns (market and intrinsic). Even with growing supermarket and high-value branded sales, there are some questions as to the extent that Namibian or Botswanan beef can out-compete local production - recall, that Nortura is the largest producer cooperative in Norway and has an interest in managing trade and competition. In Denmark, where agricultural protection is lower 
than in Norway and where retailers have more power in the chain, we observe that successful access to the Danish market by Namibia and Botswana come from strong branding efforts through "Nature's Reserve", which in addition to strong competition in general in such markets, invariably reduce the already smaller quota rents available from EU quota preferences. Such efforts are notably absent in Norway, and unlikely to be deemed necessary or desired, particularly given the involvement of the Norwegian meat industry itself in the management of SACU beef quotas.

\section{The challenge of competitiveness}

Previous research detailed the negative impact that preferential quotas have had on the overall competitiveness of Botswana and Namibia in global beef markets (Rich \& Perry 2011; Naziri et al. 2015). Indeed, one of Nortura's stated aims with their involvement in the SACU beef sector is to eventually bring beef prices in both countries to $85-90 \%$ of Norwegian levels, and indeed the analysis in section 4 highlights the steady upward movement in Namibian beef prices in particular. Given that agricultural protection in Norway affords local Norwegian producers among the highest prices for beef in the world, this potentially has two important effects.

First, it increases the reliance of Botswana and Namibia on the Norwegian markets as a means of keeping farm prices high. On a product basis, UN Comtrade data reveal that Namibia exports around 25,000 tons of beef per year, of which 9,000-10,000 tons each go to the European Union and South Africa, and just under 2,000 tons to Norway. As prices for Namibian beef sold regionally is less than the producer price for beef, rising prices for producers depend on continued access to high-priced European markets. MeatCo continues to lose money on its operations, primarily through crosssubsidization of abattoirs in the NCA and paying standard prices for cattle nationwide. While this indirectly benefits smallholder producers in the NCA and represents a positive development impact, it exposes both countries to various shocks largely out of their control. For instance, a significant outbreak of FMD in each country's FMD-free zone or other violation of SPS protocols would wipe out the industry.

Second, high prices for beef from Botswana and Namibia increase the difficulty that both countries could have in diversifying their markets, particularly from communal areas. Interviewed traders all seem to agree that there is potential for export to China 
and the Middle East, mainly for lower value cuts, through margins will certainly not match those currently available. GRN are making efforts to gain market access to new market areas, but the challenge for many of these markets is that they will be highly competitive at the low quality, where prices are low and volumes high. Given Namibia's inability to develop sufficient volumes relative to competitors in these markets (Brazil, Australia), this is not a market space that it should consider.

Is it worthwhile Namibia expending its effort in Norway to build a brand for its products when supply and demand are finite? Interviewed traders describe the Norwegian meat market as 'nationalistic' suggesting that branding could be counterproductive in that the market for such products may have a hard ceiling relative to locally produced meat. Namibia's Nature's Reserve Brand has only started to make inroads in premium Norwegian retail venues in the recent past. More success has been achieved with Nature's Reserve in Denmark (Coop 2014, 22-43).

\section{Conclusions}

There remain a degree of risk and uncertain in beef production and trade from Botswana and Namibia. Value chain actors were asked to assess the production and market landscape for the region should market access decline from its current levels and cost/productivity factors remain constant.

Namibia is left with rather limited options for market access for its Northern communal areas. Third countries like the Democratic Republic of Congo (DRC) have good prices, but poor trading practices and uncertain demand make investments in these markets risky. The Namibian government (GRN) has set up a Market Diversification Committee, recognising the risks inherent in its current reliance on the Norway.

Negotiations for SPS Agreement with China and Russia are on-going and a private study of the Chinese market for Namibian beef was conducted in 2012 (Min. of Ag, Water and Fisheries, pers comms).

In Namibia, several stakeholders talked about the possibility of domestic value addition. A canning plant is planned in Zambezi Region, as a way to get around the particular problems of an area with disease management challenges. The economics of such an operation are unclear. A long held desire to increase the value addition to leather has 
yet to materialise. For some years now, GRN has been pushing for a reduction in the export of live animals from Namibia to promote domestic value addition and this has led to some investment in abattoir capacity, particularly for small stock.

The primary strategy for Botswana is to maximise the FMD free area in the country. To do this they will invest in a new zonal approach, adopt a new traceability system based on a double ear tag and propose experimentation with forms of Commodity Based Trade (CBT). Full national FMD free coverage is always going to be a problem in areas with buffalo populations. CBT is probably the only solution for this type of area.

All informants in Botswana talked about the growth of informal/local/domestic meat processing. Those in the formal sector claimed that this type of market is unreliable and unable to take large numbers of animals. BMC would like to implement a national farm assurance scheme and plan to raise all domestic production to export standard. With existing cannery facilities for corned beef ( $90 \%$ beef), corned meat ( $45 \%$ beef) and pet food for export to South Africa, they plan a new cannery with EU compliance in the Ghanzi area in the near future.

The recent experiences of Namibian and Botswana in exporting to Norway are illustrative of a number of potential costs and benefits of using defined market access as a development policy tool. There is clear evidence that both countries have benefited financially from market access. However, the key questions are: did the market access provided by Norway deliver wider policy and social impacts desired, who benefits from the quota, what would happen if the market access were to disappear, and what lessons might be learned that could improve the beneficial impact of market access in Namibia and Botswana, and in other countries in future.

In both countries, market access to high value markets has resulted in investment in infrastructure and capacity to meet international food safety and animal health standards that would not have otherwise existed. Namibia and Botswana are rightly proud of their exports of beef because they demonstrate a hard-won ability to trade in agricultural produce to the highest global standards. This reputational benefit should not be underestimated.

The wider developmental impacts of market access are harder to measure. Market access has brought some (unmeasured and unascribed) employment and, to some extent, 
investment in infrastructure, though we have found that some of the impacts of this investment are distorting and can lead to rent capture at the level of the larger producer and particularly the main service provider/broker and actors downstream. Efforts in both countries to use market access to redress previous imbalances in the structure of rural economies cannot be said to have yet fully achieved their aims. The converse is also true, that, without this access and investment, the contribution of livestock to these economies would be considerably lower.

In both countries, continued competitiveness on global markets is still the defining question in this debate. Addressing costs through greater efficiency and novel compliance methods (e.g., CBT) are possible ways forward. Value-adding and branding efforts are critical to this, but reliance on the highly protected and parochial Norwegian market stymied innovation. Clearly, sufficient quota rents in aggregate exist to find ways to add value to products sold in Norway to the benefit of producers (and conceivably, consumers), but this will require greater awareness and participation of producers. In Namibia, the democratization of Meatco's governance structure towards functioning as a producer cooperative may facilitate such an outlook, whether the Norwegian market itself is moot.

On the question of guiding future policy, we believe that our conceptual framework provides a potential starting point for a more robust empirical analysis of the trade-offs that might occur under different policy scenarios. This issue of how gains from trade are captured and what the real benefits of trade might be needs further analysis. For example, impacts on employment and equity were hard to address in this type of qualitative analysis and would benefit from more quantification. Rigorous benchmarking of key indicators such as these followed by review should be part of the trade development process and dialogue between trading states to ensure the expected results are achieved.

The case study illustrates the importance of cut level analysis for policy makers. Traditional measures of benefits and costs in analysis of policy options in the beef trade have tended to be at a carcass level. Interviews with traders and service providers shows clearly that the contribution of profit from a carcass varies with the traders ability to differentiate cuts and select the final markets that pay the most for those cuts. The challenge faced by research at this level is that cut prices among traders are not 
publically available.

The consolidation of the regional beef export sector in Southern Africa behind an individual meat trader (GPS) as facilitated by quota rents is itself an interesting case study. Namibia and Botswana face important efficiency and scale disadvantages in international trade. Might it, therefore, be to their advantage to unify behind a single trade partner and a limited number of Norwegian traders? The cost of entry and the scale of benefits is probably low by international standards. The lesson for both countries, and others in the same position, would seem to be that balance can be achieved by regular and independent oversight. 
References

Agritrade. 2011. The cost of the closure of the EU market to Botswana's beef exports. Agritrade. http://agritrade.cta.int/Agriculture/Commodities/Beef/The-cost-of-theclosure-of-the-EU-market-to-Botswana-s-beef-exports

Amilien, V., F. Fort., and N. Ferras. 2007. Hyper-real territories and urban markets: changing conventions for local food-case studies from France and Norway. Anthropology of food, (S2). https://aof.revues.org/446 Aurdal, E., and E.L. Omholt. 2013. Norwegian beef trade with Botswana and Namibia: An analysis of the two quota-schemes. M.Sc. thesis., Norwegian University of Economics.

Bates, R. 1981. Markets and States in Tropical Africa. Berkeley. CA.: University of California Press.

Coop. 2014. Realizing Africa's Potential, Copenhagen: Herlev.

Dizyee, K., A.D. Baker., and K.M. Rich. 2017. A quantitative value chain analysis of policy options for the beef sector in Botswana. Agricultural Systems 156, 13-24. European Commission (EC). 2013a. Final report of an audit carried out in Botswana from $4^{\text {th }}$ to 11 th 2013 in order to evaluate the animal health control system in place, in particular in relation to controls on food and mouth disease, European Commission Health and Consumers Directorate-General, Food and Veterinary Office, DG (SANCO), 2013-6792.

European Commission (EC). 2013b, Final report of an audit carried out in Namibia from $19^{\text {th }}$ February to 1 March 2013 in order to evaluate the animal health control system in place, in particular in relation to controls on food and mouth disease, European Commission Health and Consumers Directorate-General, Food and Veterinary Office, DG (SANCO), 2013-6782.

Gereffi, G. 1999, International Trade and Industrial Upgrading in the Apparel Commodity Chain, Journal of International Economics, 12(1): 78-104. http://dx.doi.org/10.1016/S0022-1996(98)00075-0

Hillborn, E. 2013. Cattle, diamonds and institutions: main drivers of Botswana's Economic Development, 1850 to present. Journal of International Development. 26 (2): $155-176$

James, A. and J. Rushton. 2003. The economics of foot and mouth disease. Revue scientifique et technique (OIE), 21: 637-644. 
Kaira, C. 2018. Meat Board opens bids for Norwegian quota. Windhoek Observer. 16 November 2018. https://www.observer.com.na/index.php/business/item/10667-meatboard-opens-bids-for-norwegian-quota. Viewed 17 January 2019.

Knight-Jones, T., and J. Rushton. 2013. The economic impacts of foot and mouth disease - What are they, how big are they and where do they occur? Preventive Veterinary Medicine, 112(3-4): 161-173.

Lee, J., G. Gereffi, and J. Beauvais. 2012. Global value chains and agrifood standards: challenges and possibilities for smallholders in developing countries. Proceedings of the National Academy of Sciences, 109(31): 12326-12331. doi: 10.1073/pnas.0913714108 Meatco. 2018. Annual Report 2017/18, www.meatco.na viewed 19 January 2019. Menges, W. 2014. Witvlei Meat to fight on for export quota. The Namibia. https://www.namibian.com.na/index.php?id=121780\&page=archive-read viewed 17 January 2019.

Miescher, F. 2012. Namibia's Red Line: the History of a Veterinary and Settlement Border, Palgrave MacMillan: New York.

Mguni, M. 2019. Shift in Norwegian beef quotas could jeopardise BMC revenues. Mmegionline http://www.mmegi.bw/index.php?sid=4\&aid=1884\&dir=2010/April/Friday23/ viewed 17 January 2019.

Moreki, J. C., N.S. Ndubo., T. Ditshupo., and J.B. Ntesang. 2012. Cattle Identification and Traceability in Botswana, Journal of Animal Science Advances. 2(12): 925-933.

Retrieved from http://www.ejmanager.com/mnstemps/72/72-1354834970.pdf Mupotola, M., S. Kahurre., C. Galloway., D. Sibongo. 1997. Effects on Liberalisation on Beef and Maize Sectors in Five SADC Countries: Summary of a workshop held and Hotel Safari, Windhoek, Namibia, 2-4 December, 1996. Namibian Economic Policy Research Unit. Windhoek.

Natures Reserve. 2019. http://www.natures-reserve.co.uk viewed 19 January 2019.

Naziri, D., K.M. Rich., and B. Bennett. 2015. Would a commodity-based trade approach improve market access for Africa? A case study of the potential of beef exports from communal areas of Namibia. Development Policy Review. 33(2), 195-219. DOI: $10.1111 /$ dpr.12098

New Era. 2015. Agribank sets record straight on Witvlei abattoir, $2^{\text {nd }}$ Dec, 2015, retrieved 17 March 2016 www.newera.com.na 
New Era. 2016a. Namibia: FMD Battle Costs N\$180 Million.

https://allafrica.com/stories/201601251643.html viewed 19 January 2019.

New Era. 2016b. Agribank sets record straight on Witvlei abattoir.

https://neweralive.na/2015/12/02/agribank-sets-record-straight-witvlei-abattoir/ viewed 19 January 2019.

News Ghana. 2015. Botswana's state meat processing body faces debt and cash flow problems, 11 Apr, 2015, retrieved 29 Sept 2015 www.newsghana.com.gh

Nygård, B., and O. Storstad. 1998. De-globalization of food markets? Consumer perceptions of safe food: The case of Norway. Sociologia ruralis, 38(1), 35-53. DOI: $10.1111 / 1467-9523.00062$

Perry, B.D., T.F. Randolph., J.J. McDermott., K.R. Jones., and, P.K. Thornton. 2002. Investing in animal health research to alleviate poverty. ILRI (International Livestock Research Institute), Nairobi, Kenya.

Perry, B.D., A. Nin Pratt., K. Sones and C. Stevens. 2005. An Appropriate Level of Risk: Balancing the Need for Safe Livestock Products with Fair Market Access for the Poor. PPLPI Working Paper No. 23. Pro-Poor Livestock Policy Initiative. ILRI. Nairobi, Kenya.

Perry, B.D., and K. Rich. 2007. Poverty impacts of food-and-mouth disease and the poverty reduction impacts of its control. Veterinary Record. 160: 238-241.

Perry, B.D., and K. Sones. 2007. Poverty Reduction Through Animal Health. Science. $315(5810)$.

Rich, K.M., A. Melchior., and B. Perry. 2012. A case study of Norway's beef trade from developing countries. NUPI Working Paper 796. Oslo: Norwegian Institute of International Affairs.

Rich, K.M., and B.D. Perry. 2011. Whither Commodity-Based Trade. Development Policy Review. 29(3), 331-356. http://dx.doi.org/10.1111/j.1467-7679.2011.00536 Rich, K.M., and A. Winter-Nelson. 2007. An Integrated Epidemiological-Economic Analysis of Foot and Mouth Disease: Applications to the Southern Cone of South America. American Journal of Agricultural Economics 89 (3): 682-697.

Schlechter, D., 2014. Meatco reacts to Witvlei statements, New Era, https://neweralive.na/2014/01/15/meatco-reacts-witvlei-statements/ viewed 19 January 2019. 
Scoones, I., A. Bishi., N. Mapitse., R. Moerane., M.L. Penrith., R. Sibanda., G. Thomson., and W. Wolmer. 2010. Foot-and-mouth disease and market access: challenges for the beef industry in southern Africa. Pastoralism. 1(2): 135-164. Seleka, T. 2015. Export Competitiveness of Botswana's Beef Industry, BIDPA Working Paper 42, Botswana Institute for Development Policy Analysis, Gaborone. The Namibian, 2015. New food-and-mouth cases in Kavango West, Windhoek, 17 June 2015. https://www.namibian.com.na/index.php?id=138235\&page=archive-read viewed 19 January 2019.

The Namibian, 2016. Witvlei Meat wins back access to abattoir. https://www.namibian.com.na/149438/archive-read/Witvlei-Meat-wins-back-access-toabattoir-THE viewed 19 January 2019.

Trienekens, J. H. 2011. Agricultural Value Chains in Developing Countries: A Framework for Analysis. International Food and Agribusiness Management Review. 14(2):51-83. http://EconPapers.repec.org/RePEc:ags:ifaamr:103987 University of Greenwich., 2019. University of Greenwich Code of Practice for Research. https://www.gre.ac.uk/research/governance-and-awards/research-integrity (Accessed: 16 January 2019).

Vermes, T., 2015. Nortura har havnet I bitter kjøtt-krig I Namibia. ABCNyheter. https://www.abcnyheter.no/penger/2015/01/02/214931/nortura-har-havnet-i-bitter-kjottkrig-i-namibia viewed 19 January 2019.

Vosloo, W., A. Bastos., O. Sangare., S. Hargreaves, S., and G. Thomson. 2009. Review of the status and control of foot and mouth disease in sub-Saharan Africa. Revue scientifique et technique (OIE), 21 (3), 437-449.

Yin, R K., 2003. Case Study Research: Design and Methods, Applied social research methods series volume 5, Sage: London. 